\title{
Performance and economic analysis of growing pigs fed diets supplemented with
} different multi-enzymes complexes

*Sorunke, A. O., Adesehinwa, A. O. K., Boladuro, B. A, ${ }^{1}$ Ogunyemi, D. J., ${ }^{2}$ Abiola, J. O., ${ }^{4}$ Onarinde, O.E. and ${ }^{3}$ Adesehinwa, O. A.

Institute of Agricultural Research and Training, Obafemi Awolowo University, Ibadan

${ }^{\prime}$ Department of Animal Sciences, Obafemi Awolowo University, Ile-Ife

${ }^{2}$ Department of Veterinary Medicine, University of Ibadan, Ibadan, Nigeria.

${ }^{3}$ Ak Research Farms, Eleyele, Ibadan, Nigeria

${ }^{4}$ Department of Animal Science, University of Ibadan, Nigeria

Abstract

*Corresponding author: sorunkeadekunle@yahoo.com; +2348066621859

Consumption of high-fibre diet with non-starch polysaccharides (NSP) has the potential to adversely affect energy and nutrient utilization with consequent reduction in pig performance. This study was carried out to investigate the efficacy of three different enzymes cocktail on growth performance of growing pigs fed high-fibre diets. The basal diet served as control (T1). Treatment 2 (T2) contained $0.3 \mathrm{~g} / \mathrm{kg}$ diet of A (Xylanase, Cellulase, Protease, Alpha-amylase, Beta-glucanase, Phytase and Pectinase), treatment 3 (T3) contained 0.5 $\mathrm{g} / \mathrm{kg}$ diet of B (Carbohydrases, Beta-glucanase, Pectinase, Protease) while treatment 4 (T4) contained $0.25 \mathrm{~g} / \mathrm{kg}$ diet of $C$ (Xylanase, Phytase, Alpha - amylase, Protease, Bacillolysin). Sixty grower pigs of an average initial weight of $26.06 \pm 0.78 \mathrm{~kg}$ were randomly assigned to four dietary treatments $(T)$ in a completely randomized design with three replicates per treatment and five animals in each replicate. Feed and water were supplied ad libitum. Feed intake and weight gain of the pigs were monitored weekly. Data were subjected to analysis of variance (ANOVA) using the General Linear Model procedures of SAS (2002). There were no significant differences $(P>0.05)$ in the performance indices of the pigs though those fedenzyme cocktails had improved daily weight. Lowest feed cost per kg weight gain (\$345.38/kg) was observed in pigs fed diet supplemented with enzyme cocktail at $0.25 \mathrm{~g} / \mathrm{kg}$. It was concluded that cocktail of enzymes improved daily weight gain of growing pigs fed diets containing non-starch polysaccharides. Also, enzymes cocktail $(0.25 \mathrm{~g} / \mathrm{kg})$ reduced feed cost per kilogram weight gain of the pigs.

Keywords:Growing pigs, enzymes cocktail, Non-starch polysaccharides, weight gain, economic analysis

\section{Performance et analyse économique de porcs en croissance nourris avec des régimes supplémentés de différents complexes multi-enzymatiques}

\section{Résumé}

$\overline{\text { La consommation d'aliments riches en fibres avec des polysaccharides non amylacés (NSP) }}$ a le potentiel d'affecter négativement l'utilisation de l'énergie et des nutriments avec une réduction conséquente des performances des porcs. Cette étude a été réalisée pour étudier l'efficacité de trois cocktails d'enzymes différents sur les performances de croissance de porcs en croissance nourris avec des régimes riches en fibres. Le régime de base a servi de contrôle (T1). Le traitement 2 (T2) contenait 0,3 $\mathrm{g} / \mathrm{kg}$ de régime A (Xylanase, Cellulase, Protéase, Alpha-amylase, Bêta-glucanase, Phytase et Pectinase), le traitement 3 (T3) contenait $0,5 \mathrm{~g} / \mathrm{kg}$ de régime $B$ (Carbohydrases, Bêta -glucanase, Pectinase, Protease) tandis que le traitement 4 (T4) contenait $0,25 \mathrm{~g} / \mathrm{kg}$ de ration de C (Xylanase, Phytase, Alpha- 


\section{Performance and economic analysis of growing pigs}

amylase, Protease, Bacillolysin). assignés à quatre traitements diététiques (T) dans une conception complètement randomisée avec trois répétitions par traitement et cinq animaux dans chaque répétition. La nourriture et l'eau étaient fournies ad libitum. La prise alimentaire et le gain de poids des porcs ont été surveillés chaque semaine. Les données ont été soumises à une analyse de variance (ANOVA) à l'aide des procédures du modèle linéaire général de $S A S$ (2002). Il n'y avait pas de différences significatives $(P>0,05)$ dans les indices de performance des porcs bien que ceux nourris avec des cocktails enzymatiques aient amélioré leur poids quotidien. Le coût alimentaire le plus bas par $\mathrm{kg}$ de gain de poids (\$345,38/kg) a été observé chez les porcs nourris avec un régime supplémenté avec un cocktail d'enzymes à $0,25 \mathrm{~g} / \mathrm{kg}$. Il a été conclu que le cocktail d'enzymes améliorait le gain de poids quotidien des porcs en croissance nourris avec des régimes contenant des polysaccharides non amylacés. De plus, le cocktail d'enzymes $(0,25 \mathrm{~g} / \mathrm{kg})$ a réduit le coût des aliments par kilogramme de gain de poids des porcs.

Mots clés : Porcs en croissance, cocktail d'enzymes, Polysaccharides non amylacés, prise de poids, analyse économique

\section{Introduction}

Soluble nonstarch polysaccharides (NSP) have anti-nutritional effect and cannot be degraded by pigs because pigs cannot excrete NSP enzymes. Therefore, there has been considerable interest in applying exogenous non-starch polysaccharides degrading enzyme preparations for potential benefits. The effects of exogenous enzymes on growth performance and nutrient digestibility may be influenced by enzyme preparations, the physiological status of the animal and feed ingredient. Soluble nonstarch polysaccharides (NSP) have anti-nutritional effect and cannot be degraded by pigs because pigs cannot excrete NSP enzymes. Therefore, there has been considerable interest in applying exogenous non-starch polysaccharides degrading enzyme preparations for potential benefits. The effects of exogenous enzymes on growth performance and nutrient digestibility may be influenced by enzyme preparations, the physiological status of the animal and feed ingredient

Soluble nonstarch polysaccharides (NSP) have anti-nutritional effect and cannot be degraded by pigs because pigs cannot excrete NSP enzymes. Therefore, there has been considerable interest in applying exogenous non-starch polysaccharides degrading enzyme preparations for potential benefits. The effects of exogenous enzymes on growth performance and nutrient digestibility may be influenced by enzyme preparations, the physiological status of the animal and feed ingredient.

Recent trends in the demand and supply of conventional feedstuffs necessitate swine producers around the globe to look for lowcost alternatives such as co-products from milling industries to feed their pigs at the expense of feed costs reduction (Woyengo et al., 2014). Many of these co-products have been reported to have a high energy and nutrient content but they are also fibrous in nature. When fibrous co-products are integrated into pig diets, the carbohydrate structure inevitably deviates from a high-starch diet toward a diet with less starch and more non-starch polysaccharides (NSP), which are the major components of dietary fibre(Agyekum andNyachoti, 2017). Pigs lack ability to secrete the digestive enzymes required to break down non-starch polysaccharides, but have the capacity to secrete the enzymes needed to hydrolyze starch (Zijlstra et al., 2012). Generally, diets that are rich in dietary fibre have a lower nutritive value for monogastric animals, including pigs, because these animals' digestive enzymes are not capable of degrading non-starch polysaccharides(Bedford andSchulze, 
1998). These non-starch polysaccharides have been proven to be unbroken by the activities of endogenous enzymes, therefore causing adverse effect by encapsulating other nutrients, increasing the endogenous nutrient loss, and then result in lower nutrient and energy digestibility (Adeola andCowieson, 2011; Kerr and Shursn, 2013). The consumption of high-fiber diets also has the potential to adversely affect energy and nutrient utilization and consequently results in lower pig performance (Agyekum et al., 2014; Agyekum et al., 2015). Therefore, it is of utmost importance to supplement the appropriate NSP enzyme, especially NSP enzyme cocktail (NSPEC), in a variety of feeds to degrade the anti-nutrient factor (NSP) and improve growth performance of animals.According to Agyekum and Nyachoti (2017), quite a number ofapproacheshave been employed to ameliorate the adverse effects linked with the consumption of high-fiber diets in pigs and to improve the nutritive value of such diets. The use of exogenous fibre-degrading enzymes to improve nutrient utilization and pig performance has been widely accepted. Previous studies showed that the supplementation of NSP enzyme complex ( $\beta$-glucanase and xylanase) improved average daily gain of weaned and growing pigs (Prandini et al., 2014).In addition, some studies observed that a complex of non-starch polysaccharide-degrading enzymes could improve the growth performance of the weaned piglets and growing-finishing pigs (Jo et al., 2012; Yi et al., 2013). However, (Olukosi et al., 2007) did not observe a positive effect of enzyme cocktail supplementation on growth performance of pigs. The effects of fibredegrading exogenous enzymes in fiber-rich pig feeds among studies remain inconsistent. This may be attributed to variations in the components of the enzyme cocktail. Many of the aforementioned studies used enzyme cocktail of two or three enzymes combinations. Therefore, the study was aimed at assessing the effect of cocktail enzymeson the growth performance of grower pigs fed diets containing non-starch polysaccharides.

\section{Materials and methods}

\section{Experimental location and duration}

The experiment was conducted at AK Research Farms located at Eleyele, Ibadan, Oyo state, Nigeria and it lasted for a period of 63 days.

\section{Experimental diets, animals and management}

A basal diet that met the nutrient requirement of growing pigs was formulated using National Research Council (2012) as a guide. The diet was formulated using maize, palm kernel cake, wheat bran, corn bran and groundnut cake. The basal diet served as a control treatment ( T 1) and contained no enzyme supplementation. Three additional treatments $(\mathrm{T})$ were prepared by adding different cocktail of enzymes (A, B and C) to the basal diets. Treatment 2 (T2) contained $0.3 \mathrm{~g} / \mathrm{kg}$ diet of A (Xylanase, Cellulase, Protease, Alpha-amylase, Betaglucanase, Phytase and Pectinase), treatment 3 (T3) contained $0.5 \mathrm{~g} / \mathrm{kg}$ diet of B (Carbohydrases, Beta-glucanase, Pectinase, Protease) while treatment 4 (T4) contained $0.25 \mathrm{~g} / \mathrm{kg}$ diet of $\mathrm{C}$ (Xylanase, Phytase, Alpha - amylase, Protease, Bacillolysin).These enzymes were sourced from Agro allied companies in Nigeria.Sixty growing cross bred (Large white $\times$ Landrace) pigs of average initial live weight of $26.06 \pm 0.78 \mathrm{~kg}$ were used for the study. The pigs were allotted to the four experimental treatments. Each treatment consisted of three replicates and each replicate had five animals. The animals were placed in concrete pens with concrete water trough and semi-automatic feeders. The animals were fed with the experimental 
diets throughout the experimental period. Feed and water were given unrestrictedly.
Standard management practices were duly followed.

Table 1: Gross composition of the experimental diet

\begin{tabular}{lllll}
\hline Ingredients (\%) & $\mathrm{T} 1$ & $\mathrm{~T} 2+\mathrm{A}$ & $\mathrm{T} 3+\mathrm{B}$ & $\mathrm{T} 4+\mathrm{C}$ \\
\hline Maize & 15.00 & 15.00 & 15.00 & 15.00 \\
Palm kernel cake & 50.00 & 50.00 & 50.00 & 50.00 \\
Corn bran & 10.00 & 10.00 & 10.00 & 10.00 \\
Wheat bran & 10.00 & 10.00 & 10.00 & 10.00 \\
Groundnut cake & 11.00 & 11.00 & 11.00 & 11.00 \\
Bone meal & 2.30 & 2.30 & 2.30 & 2.30 \\
Oyster shell & 1.20 & 1.20 & 1.20 & 1.20 \\
Salt & 0.30 & 0.30 & 0.30 & 0.30 \\
Lysine & 0.20 & 0.20 & 0.20 & 0.20 \\
Premix & 0.25 & 0.25 & 0.25 & 0.25 \\
Threonine & 0.03 & 0.03 & 0.03 & 0.03 \\
Anti-fly guard & 0.05 & 0.05 & 0.05 & 0.05 \\
Enzymes & - & 0.03 & 0.05 & 0.025 \\
\hline Total & 100.33 & 100.33 & 100.33 & 100.33 \\
\hline Calculated values & & & & \\
Metabolizable energy Kcal/kg & 2617.50 & 2617.50 & 2617.50 & 2617.50 \\
Crude protein & 17.54 & 17.54 & 17.54 & 17.54 \\
Crude fibre & 8.51 & 8.51 & 8.51 & 8.51 \\
\hline
\end{tabular}

Note: the total does not include the enzymes

A: Enzyme cocktail (Xylanase, Cellulase, Protease, Alpha -amylase, Beta-glucanase, Phytase and pectinase), B:enzyme cocktail (Carbohydrases (beta -glucanase), Pectinase, Protease), C: enzyme cocktail (Xylanase, Phytase, Alpha-amylase, Protease, Bacillolysin)

Data collection and statistical analysis

Weekly feed intake and body weight gain were monitored. Feed conversion ratio average daily weight gain and average daily feed intake were calculated. Feed conversion ratio was calculated by dividing total feed consumed by each animal by its respective total body weight gained. Daily weight gained was derived by dividing total body weight gained by the number of experimental days while daily feed intake was calculated by dividing the actual feed intake of each animal by the number of experimental days.

\section{Economic of production}

The cost per kg of the diet was calculated by multiplying the percentage composition of the feedstuffs with the prevailing price per $\mathrm{kg}$ of each feedstuff and summing all. Total feed intake and cost per kg of feed was used to calculate the total feed cost. Feed cost per $\mathrm{kg}$ weight gain was calculated by multiplying feed conversion ratio (FCR) with cost per kg diet.Data were subjected to analysis of variance (ANOVA) appropriate for completely randomized design using the General Linear Model procedures of SAS (2002). Statistical significance was assessed at $\mathrm{P}<0.05$ (95\% confidence) while means were separated using Duncan's Multiple Range Test.

\section{Results and discussion}

\section{Growth performance of growing pigs fed different cocktail enzymes}

Table 2 shows the performance characteristics of grower pigs fed the experimental diets. There was no significant ( $p>0.05)$ effect of the treatment on the growth performance indices of the animals. The final body weight ranged from 46.37 to $48.14 \mathrm{~kg}$ with pigs fed diet contained 


\section{Sorunke, Adesehinwa, Boladuro, Ogunyemi, Abiola, Onarinde and Adesehinwa}

cocktail enzymes B (Carbohydrases, Betaglucanase, Pectinase and Protease) having the highest final body weight while cocktail enzyme C (Xylanase, Phytase, Alpha amylase, Protease, Bacillolysin) had the lowest final body weight. In terms of body weight gain, pigs fed cocktail enzyme supplemented diets had improved body weight gains compared those fed nonsupplemented diet (control). The pigs fed control diet had body weight gain of 19.36 $\mathrm{kg}$ while those in supplemented groups had values ranged from 21.40 to $22.04 \mathrm{~kg}$. Among the enzyme-supplemented groups, pigs fed diet supplemented with cocktail enzymes B had better body weight gain $(22.04 \mathrm{~kg})$ than those fed diets supplemented with cocktail enzymes A and B . There were $9.5,12.2$ and $9.5 \%$ improvements in body weight gains of pigs fed diets with enzyme supplementation respectively for cocktail of enzymes A, B and $\mathrm{C}$ when compared with those pigs on control diet. It is worthy of note that pigs fed diet supplemented with cocktail enzymes had same body weight gains despite the differences in their compositions. Although, cocktail of enzymes A contained all the components of cocktail of enzymes $\mathrm{C}$ with the exception of Bacillolysin in addition with cellulase, beta-glucanase and pectinase. Bacillolysin in cocktail of enzymes $\mathrm{C}$ seems to have performed altogether the functions of cellulase, betaglucanase and pectinase in cocktail of enzymes A which probably resulted in no significant difference in the body weight gains of the pigs. The daily weight gain of the pigs across the treatments followed similar pattern with their body weight gains. The daily weight gains ranged from 0.307 to $0.350 \mathrm{~kg}$. There exists no significant $(p>0.05)$ differences in the daily feed intake and feed conversion ratio (FCR) of the pigs across the treatments. The daily feed intake ranged from 1.339 to $1.507 \mathrm{~kg}$. Pigs fed diet supplemented with cocktail of enzymes B had higher daily feed intake while those on the control diet has the lowest daily feed intake. The feed conversion ratios were also similar among the treatments with pigs fed diet supplemented with cocktail of enzymes $\mathrm{C}$ having the least FCR (4.126) while the highest FCR (4.362) was noticed in pigs fed non-supplemented diet (control).

Although, there was no significant difference but the improvement in body weight gain observed in this study is in agreement with the earlier finding of Prandini et al. (2014), who reported better weight gain in weaned and growing pigs fed diets supplemented with cocktail of enzymes (beta-glucanase and xylanase). The earlier report of Wanget al. (2018) disagreed with the findings of this study. The authors reported improvement in the weight gain of weanling pigs as a result of inclusion of multi-enzyme in a cornsoyabean meal-based diet. The disparity in the outcomes could be due to age difference of the experimental animals. Insignificant effect of the cocktail of enzymes in this study may be an indication that grower pigs have a well-developed gastro-intestinal tract (GIT) with sufficient amount of beneficial microbes while significant effect of multi-enzymes reported by Wang et al. (2018) served as a shred of evidence that the GIT of weaner pigs is underdeveloped with insufficient endogenous enzymes and microbiota. The earlier findings of Kim et al.(2008) on combination of xylanase with phytase and protease showed positive effects on energy and nutrient digestibility in barrows fed diet containing 20\% distiller's dry grain. This is not in consonant with the results of the present study; eventhough the present study did not evaluate nutrient digestibility but better growth performance. In an experiment with broilers chicken, increased fermentation of xylans in the caeca of birds fed xylanase supplemented diet was noted in older but not younger birds, suggesting that there is 


\section{Performance and economic analysis of growing pigs}

indeed an adaption of the microbiome over time, enabling it to utilize xylan as a significant fuel for production of volatile fatty acids (Leeet al., 2017a). The illustration above further strengthens the notion that enzymes may not make any significant difference in older animals compare to younger ones because of the capability of older animals to secrete endogenous enzymes and proliferation of beneficial microbes.

Table 2: Performance of growing pigs fed experimental diets

\begin{tabular}{lcccccc}
\hline Parameters (per pig) & T1 & T2 & T3 & T4 & SEM & P-value \\
\hline Initial body weight $(\mathrm{Kg})$ & 27.214 & 25.967 & 26.107 & 24.967 & 0.7826 & 0.8018 \\
Final body weight $(\mathrm{Kg})$ & 46.571 & 47.367 & 48.143 & 46.367 & 1.2558 & 0.9607 \\
Body weight gain $(\mathrm{Kg})$ & 19.357 & 21.400 & 22.036 & 21.400 & 0.8838 & 0.7470 \\
Daily weight gain $(\mathrm{Kg})$ & 0.307 & 0.340 & 0.350 & 0.340 & 0.0140 & 0.7470 \\
Daily feed intake $(\mathrm{Kg})$ & 1.339 & 1.432 & 1.507 & 1.403 & 0.0288 & 0.4106 \\
Feed conversion ratio & 4.362 & 4.212 & 4.306 & 4.126 & 0.2328 & 0.8413 \\
\hline
\end{tabular}

SEM; standard error of means

Economic analysis of growing pigs fed diet with different cocktail of enzymes

In order to have meaningful conclusions on whether to recommend a particular product for farmers, economic benefits of using such a product must be clarified. The economic analyses of using each of these products are presented in Table 3. The cost of feed per kilogram ranged from -82.62 to -84.77 with control diet having the least value while the highest value was observed in diet supplemented with enzyme cocktail B. The variations observed in the cost of feed across the treatments were as a result of differences in the price of the supplements. Total costs of feeding throughout the experiment were not significantly $(\mathrm{p}>0.05)$ different from one another. The animal placed on diet with enzyme cocktail B consumed more feed than the rest, hence higher total cost of feeding $(-8,047)$. Total cost of feeding animals on the control diet was the least $(-6,973)$. Total costs of feeding animals placed on diets supplemented with enzyme cocktail A and $\mathrm{C}$ were in close range due to similar cost of feed and feed consumption. Similar trends were noticed in the average cost of feeding per day. The cost of feed that was consumed by the animal that yielded a kilogram live weight of the animal was also estimated. The cost of producing a kilogram live weight of the animal was highest $(-366.52)$ in pigs fed diet supplemented with enzyme cocktail B while the least value $(-345.38)$. This means it was cheaper to produce a kilogram live weight of pig using enzyme cocktail $\mathrm{C}$ when compared with enzyme cocktail A and B under the nature of this experimental basal diet. Feeding diets supplemented with enzyme cocktail $\mathrm{C}$ is more economical than enzyme cocktail A,B and the control diet.

Table 3: Economic analysis of growing pigs fed experimental diets

\begin{tabular}{lllllll}
\hline Parameters & T1 & T2 & T3 & T4 & SEM & P-value \\
\hline Cost of feed (-/kg) & 82.62 & 83.33 & 84.77 & 83.42 & - & - \\
Total cost of feeding (-) & 6973 & 7516 & 8047 & 7376 & 345.25 & 0.8115 \\
Average cost of feeding/day $(-)$ & 110.69 & 119.29 & 127.73 & 117.08 & 5.623 & 0.8115 \\
Feed cost/kg weight gain $(-/ \mathrm{kg})$ & 361.40 & 350.06 & 366.52 & 345.38 & 8.624 & 0.8542 \\
\hline
\end{tabular}

SEM; standard error of means 


\section{Conclusions and recommendation}

The study concluded that cocktail enzymes supplementation did not improved daily weight gain of growing pigs. However, supplementing cocktail enzyme $\mathrm{C}$ to diet with non-starch polysaccharide produced a kilogram live weight of pig at a cheaper rate, therefore enzyme cocktail $\mathrm{C}$ could be recommended.

\section{Acknowledgement}

The authors wish to appreciate the management and staff of AK Research Farms, Eleyele, Ibadan, for releasing their facilities and the support enjoyed through the course of theresearch. Also, our appreciation goes to Midcentury Agro Allied Ventures Limited for donating one of the enzymes cocktail.

\section{Competing interest}

The authors declare no conflict of interest.

\section{References}

Adeola, O. and Cowieson, A. 2011. B o a rd-invited review : Opportunities and challenges in using exogenous enzymes to improve nonruminant animal production. Journal of animal science, 89:3189-3218.

Agyekum, A. K., Sands, J. S., Regassa, A., Kiarie, E., Weihrauch, D.and Kim, W. K. 2015. Effect of supplementing a fibrous diet with a xylanase and $\beta$-glucanase blend on growth performance, intestinal glucose uptake, and transportassociated gene expression in growing pigs. Journal of Animal Science, 93(7):3483-93.

Agyekum, A. K., Woyengo, T. A., Slominski, B. A., Yin, Y. L. and Nyachoti, C. M. 2014. Effects of formulating growing pig diet with increasing levels of wheat-corn distillers dried grains with solubles on digestible nutrient basis on growth performance and nutrient digestibility. Journal of Animal Physiology and Animal Nutrition, 98 (4):651-8.

Agyekum, A. K. and Nyachoti C. M. 2017. Nutritional and metabolic consequences of feeding highfiberdiets to swine: A review. Engineering 3:716-725

Bedford, M. R.and Schulze, H. 1998. Exogenous enzymes for pigs and poultry. Nutrition Research Review, 11(1):91-114.

Jo, J. K., Ingale, S. L., Kim, J. S., Kim, Y. W., Kim, K. H., Lohakare, J. D., Lee, J. H. and Chae, B. J. 2012. Effects of exogenous enzyme supplementation to corn- and soybean meal-based or complex diets on growth performance, nutrient digestibility, and blood metabolites in growing pigs. Journal of Animal Science, 90:3041-3048.

Kerr, B. J.and Shurson, G. C. 2013. Strategies to improve fiber utilization in swine. Journal of Animal Science and Biotechnology, 4, 11 .

Kim, Y., Mosier, N. S., Hendrickson, R., Ezeji, T., Blaschek, H., Dien, B., Cotta, M., Dale, B. andLadisch, M. R. 2008. Composition of corn dry-grind ethanol by-products: $D D G S$, wet cake and thin stillage. Bioresource Technology 99: 51655176.

Lee, S. A., Apajalahti, J., Vienola, K., Gonzalez-Ortiz, G., Fontes, C. M. G. A. and Bedford, M. R.2017a. "Age and Dietary Xylanase Supplementation Affects Ileal Sugar Residues and Short Chainfatty Acid Concentration in the Ileum and Caecum of Broiler Chickens." Animal Feed Science 
and Technology 234:29-42.

National Research Council 2012. Nutrient Requirements of Swine; Eleventh, R., Ed.; National Academies Press:Washington, $D C$, USA; ISBN 978-0-309-22423-9..

Olukosi, O., Sands, J. and Adeola, O. 2007. Supplementation of carbohydrases or phytase individually or in combination to diets for weanling and growingfinishing pigs. Journal Animal Science, 85, 1702-1711.

Prandini, A., Sigolo, S., Morlacchini, M., Giuberti, G., Moschini, M., Rzepus, M. and Della Casa, G. 2014. Addition of nonstarch polysaccharides degrading enzymes to two hulless barley varieties fed in diets for weaned pigs. Journal of Animal Science, 92, 2080-2086.

Wang,Y. Chiba, L.I., Huang, C, Torres, I.M., Wang, L.and Welles, E. G. 2018. Effect of diet complexity, multi-enzyme complexes, essential oils, and benzoic acid on weanling pigs. Livestock Science 209: $32-38$
Woyengo, T. A., B e l t r a n e na, E.andZijlstra, R. T. 2014.Nonruminant Nutrition Symposium: Controlling feed cost by including alternative ingredients into pig diets: A review. Journal of Animal Science, 92(4):1293-305.

Yi, J. Q., Piao, X.S., Li, Z. C., Zhang, H. Y., Chen, Y., Li, Q. Y., Liu, J. D., Zhang, Q., Ru, Y. J. andDong, B. 2013. The effects of enzyme complex on performance, intestinal health and nutrient digestibility of weaned pigs. Asian AustralianJournal of Animal Science, 26, 1181-1188.

Zijlstra, R. T., Jha, R., Woodward, A. D., Fouhse, J. and van Kempen, T. A.2012. Starch and fiber properties affect their kinetics of digestion and thereby digestive physiology in pigs. Journal of Animal Science, 90(4):49-58.

Received: $10^{\text {th }}$ May, 2021

Accepted: 25 $5^{\text {th }}$ August, 2021 